BLS 32, No 1 2006. DOI: http://dx.doi.org/10.3765/bls.v32i1.3474 (published by the Berkeley Linguistics Society and the Linguistic Society of America)

\title{
Unergative Verbs in Norwegian Intransitive Expletive Constructions
}

\author{
KJERSTI G. STENSRUD \\ University of Chicago
}

\section{Introduction}

Intransitive expletive constructions (IECs) in Norwegian occur with both unaccusative and unergative verbs.

(1) Det forsvant en skatt i havet. there disappeared a treasure in the.ocean

'A treasure disappeared in the ocean.'

(2) Det jobber en mann i skogen.

there works a man in the.forest

'A man is working in the forest.'

To account for (1) is fairly straightforward; the object of the unaccusative has remained in its base generated position, with the expletive satisfying the EPP. The occurrence of the unergative jobbe 'work' in (2) carries far more theoretical interest, as unergatives are commonly assumed to combine with an external argument. Previous analyses have generally posited the same structure for both unaccusative and unergative IECs, assuming unergative IECs to involve a marked realization of agents as syntactic objects.

In this paper I provide strong empirical evidence in favor of disassociating unaccusative and unergative IECs. I further show that unergative IECs more closely resemble expletive copula constructions in Norwegian. On the basis of this, I develop an analysis of unergative IECs as verbal existentials, where I propose that unergatives in IECs function analogous to copulas.

The discussion is structured as follows. I start by introducing the basic properties of Norwegian IECs. I then provide a brief overview of some of the earlier unified IEC-analyses and show that they fail to capture a group of salient differences between unaccusative and unergative IECs. Then I discuss the relation between unergative IECs and expletive copula constructions in Norwegian, and 


\section{Kjersti G. Stensrud}

develop an existential analysis of unergative IECs on the basis of this. The last section summarizes the discussion.

\section{Norwegian Intransitive Expletive Constructions: Data}

Expletive constructions with intransitives feature both unaccusative and unergative verbs, as illustrated by the following examples. ${ }^{1}$

\section{Unaccusatives:}

(3) Det sank et skip i havet.

there sunk a ship in the.ocean

'A ship sunk in the ocean.'

(4) Det døde mange mennesker i flyulykken.

there died many people in the.plane.crash

'Many people died in the plane crash.'

\section{Unergatives:}

(5) Det jobber en mann i hagen.

there works a man in the.garden

'A man works in the garden.'

(6) Det kjørte mange biler over broa.

there drove many cars over the.bridge

'Many cars drove over the bridge.'

Crucially, there are other constructions that do distinguish between unaccusatives and unergatives in Norwegian, for instance adjectival and impersonal passives.

The only type of verb that is excluded from these constructions is unergatives referring to internal states of a human being, like tenke 'think' and føle 'feel.'

(7) *Det tenker en jente på biblioteket. there thinks a girl in the.library

(8) *Det føler en dikter på poesifestivalen.

there feels a poet on the.poetry.festival

Like the other mainland Scandinavian languages, Norwegian does not have the transitive expletive constructions that we find in Icelandic.

\footnotetext{
${ }^{1}$ Thematic subjects in IECs are strictly subject to the Definiteness Effect.
} 


\section{Unergatives in Norwegian Expletive Constructions}

(9) मað hefur einhver borðað epli.

there has someone.NOM eaten apple.ACC

'Someone has eaten an apple.'

(10) *Det har noen spist et eple.

there has someone eaten an apple

Unlike in the transitive expletive constructions, the thematic subject appears post-verbally in IECs, as becomes evident when an auxiliary is present and the main verb remains inside the VP.

(11) Det har jobbet en mann i hagen.

there has worked a man in the.garden

'A man has worked in the garden.'

*Det har en mann jobbet $i$ hagen.

there has a man worked in the.garden

Furthermore, the post-verbal DP obligatorily appears immediately after the verb, before any adverbial phrases.

(13) Det jobber (ofte) en mann (*ofte) i hagen.

there jobber often a man often in the.garden

'A man often works in the garden.'

*Det forsvant i havet en skatt.

there disappeared in the.ocean a treasure

The position of the post-verbal DP thus appears to correspond to a regular object position. This has commonly led to the assumption that the thematic subject is realized as object in both unaccusative and unergative IECs. I now proceed to a discussion of some of the unified IEC-analyses that have emerged from this assumption.

\section{Previous Analyses: Unified Approaches to IECs}

Previous discussions of IECs generally assume that unergative and unaccusative IECs are structurally identical: the thematic agent subject is realized as object with the expletive subject satisfying the EPP (e.g. Sveen 1997, Lødrup 1999, Mikkelsen 2001 for Danish). 
Kjersti G. Stensrud

(15)

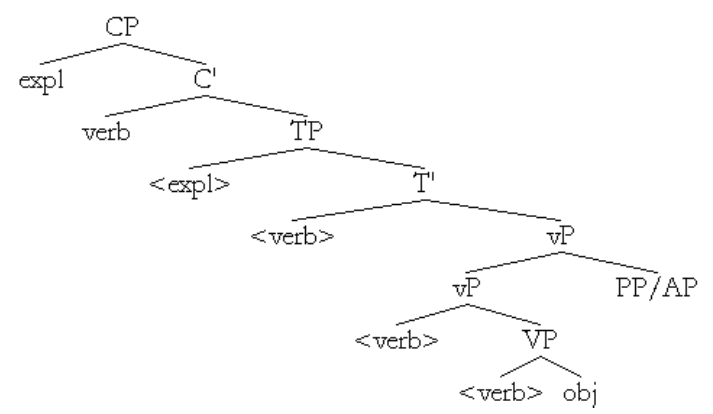

The structure in (15) provides a fairly straightforward account of unaccusative IECs: the object remains in its base generated position with the expletive satisfying the EPP.

The assumption that the structure in (15) is the correct analysis also for unergative IECs is of far more theoretical interest. This of course pertains to the conflation of unergatives and unaccusatives in these constructions, more specifically the realization of unergative arguments as objects. The apparent mapping of agents onto object positions contradicts the assumptions of the U(T)AH. Theoryspecific claims aside, the association between the agent and syntactic subject (crucially as a one-way implication) is the one association that seems to hold for the lexicon-syntax interface across languages (e.g. Levin and Rappaport Hovav 2005). Unified approaches to IECs are thus faced with the theoretical task of determining what mechanisms underlie the "unaccusativization" of unergative verbs in IECs.

In addition to some conceptual challenges, the unified accounts face a set of empirical problems: there are salient differences between unaccusative and unergative IECs which the unified accounts fail to accommodate.

\section{Structural Differences Between Unergative and Unaccusative IECs}

Unaccusative and unergative IECs differ in (at least) three ways: i) with respect to limitations on what verbs may appear in the construction, ii) requirements on the presence of a locative predicate, and iii) constituency. I address these differences in turn.

As was mentioned in brief in 2.1, all unaccusative verbs may occur in IECs, whereas the use of unergatives is restricted. Some unergative verbs are entirely excluded from the construction, namely the 'internal activity' verbs we saw in (7)-(8) repeated here for convenience.

*Det tenker en jente på biblioteket. there thinks a girl in the.library

(17) *Det føler en dikter på poesifestivalen. there feels a poet on the.poetryfestival 


\section{Unergatives in Norwegian Expletive Constructions}

On a unified IEC-account, it is not clear why what appears to be a restriction on whether the activity described by the verb relates to physical space would apply only to unergative verbs. For instance, the distinction between two unaccusative verbs like die and sink is not that different from the relation between think and sit in this respect. Still the restriction only applies to the latter.

The second difference between unergative and unaccusative IECs is that unergative IECs require the presence of a locational predicate.

Det løper en gutt *(på veien/ over jordet/ her ... etc.). there runs a boy on the.road/across the.field/ here ... 'A boy runs (on the road/across the field/here ... ).'

Naturally, no locational predicate is obligatory with a regular (i.e. non-expletive) intransitive.

Gutten løper (på veien/ i skogen / over jordet ... etc.). the.boy runs on the.road/ in the.forest/ across the.field ... 'The boy runs (on the road/ ... etc.).'

The locational predicate can either signify a location (on the road) or a path (across the field) and may be either a prepositional phrase or a locative adverbial (here/there). Temporal PP/APs are not acceptable.

$$
\begin{aligned}
& \text { *Det løp en gutt i går/da. } \\
& \text { there ran a boy in yesterday/then }
\end{aligned}
$$

Furthermore, the locational predicate must immediately follow the post-verbal thematic subject.

$$
\begin{aligned}
& \text { Det løp en gutt } \quad{ }^{*} \text { i går) } \\
& \text { there ran a boy } \quad \text { in yesterday in the.forest }
\end{aligned}
$$

This indicates that the locational predicate is in fact selected by the verb. The required presence of locative predicate points back to the restrictions on unergative verbs in IECs - location evidently plays a crucial role in these constructions.

With unaccusative IECs, a locative predicate is optional, and the locative predicate (if present) behaves like any other adjunct with respect to adjacency.

(22) Det forsvant en skatt (i havet/ i brannen/ der...) there disappeared a treasure in the.ocean/in the.fire/ there ... 'A treasure disappeared (in the ocean/in the fire/there).' 


\section{Kjersti G. Stensrud}

(23) Det har sunket mange skip (gjennom tidene) i Atlanterhavet. there has sunk many ship through the.times in the.Atlantic.Ocean 'Many a ship has sunk in the Atlantic Ocean over the years.'

A third difference emerges with respect to constituency. If the thematic subject is realized as object in both unaccusative and unergative IECs, we expect the verb and the thematic subject to form a constituent in both cases. Looking at the possibility of VP-coordination in unaccusative and unergative IECs, this prediction is not borne out. As we would expect, the verb and post-verbal DP in unaccusative IECs can be coordinated.

Det har [visnet en blomst] og [dødd et tre] $i$ hagen. there has withered a flower and died a tree in the.garden 'A flower has withered and a tree has died in the garden.'

Det [forsvant noen småbåter] og [sank et par skip]. there disappeared some small.boats and sunk a couple ships 'Some small boats disappeared and a couple of ships sunk.'

However, coordination is not possible with the unergative IECs. ${ }^{2}$

*Det har [løpt en rev] og [hoppet en kanin] over jordet. there has ran a fox and jumped a rabbit over the.field

*Det [lekte mange barn] og [jobbet mange menn] i parken. there played many children and worked many men in the.park

The relation between the verb and the thematic subject thus appears to be essentially different from that in unaccusative IECs.

In sum, there are substantial differences between unergative and unaccusative IECs that the unified IEC-analyses fail to account for. More specifically, the unaccusative structure in (15) does not provide an adequate analysis of the unergative cases.

\section{Unergative IECs as Verbal Existentials}

In this section I develop an alternative that captures the particular syntactic and semantic properties of unergative IECs. I show that unergative IECs bear a close syntactic and semantic resemblance to existential copula constructions and argue on the basis of this that they ought to be analyzed as verbal existentials. This analysis elaborates on an idea initially explored in Hoekstra and Mulder (1990): a group of unergative verbs have the option of combining either with an agent DP

\footnotetext{
${ }^{2}$ Note that we do get Right Node Raising constructions with unergative IECs, crucially involving the intonational break associated with RNRs. The unacceptable examples in (26) and (27) reflect structures where no such break is present, i.e. regular conjunction.
} 


\section{Unergatives in Norwegian Expletive Constructions}

or with a small clause complement, the former yielding agentive intransitives and the latter giving rise to unergative IECs.

\subsection{Unergative IECs and Expletive Copular Constructions}

A requirement of a predicate following the thematic subject is also found with expletive copular constructions in Norwegian.

Det er en elg *( $i$ hagen).

there is a moose in the.garden

'There is a moose in the garden.'

Like we saw with the unergative IECs, nothing can intervene between the thematic subject and this predicate.
Det var en elg *(hver dag) i hagen.
there was a moose every day in the.garden

Note however, that expletive copula constructions differ from IECs by also allowing temporal predicates in some cases.

\section{Det var en fest etter middag.} there was a party after dinner

'There was a party after dinner.'

This seems to be related to the fact that the copula allows for thematic subjects referring to events. As will be discussed further below, both unergative IECs and expletive copula constructions state the existence of an entity relative to some location. Unergatives typically require animate subjects, and to locate animates (as well as other physical objects) in time is conceptually problematic. As we would expect, temporal predicates in expletive copula constructions are unacceptable when the thematic subject refers to a physical object.

\section{*Det var en elg etter middag. there was a moose after dinner}

Events on the other hand may naturally be located in time, and this explains why temporal predicates occur with expletive copular constructions. Unergative IECs and expletive copula constructions thus share a strict requirement of a locational predicate, which may refer either to physical or temporal locations depending on the nature of the thematic subject. ${ }^{3}$

\footnotetext{
${ }^{3}$ Note that the use of expletive copula constructions in Norwegian is limited to predication of location (physical or temporal), and thus more restricted than what we find e.g. in English. As was shown above, Norwegian does not allow for only a thematic subject after the copula.
}

(i) There's a man / *Det er en mann. 
Crucially, there is also a close semantic relation between unergative IECs and expletive copular constructions. Like expletive copula constructions, unergative IECs assert the existence of an entity in the location denoted by the locational predicate. This existence is further characterized by the unergative verb such as working, running, etc. A sentence like Det jobber en mann $i$ hagen ('there works a man in the garden') could be paraphrased as 'There is a man in the garden such that he is working.'

Note that unaccusative IECs with locative PPs do not have this existential interpretation. For a sentence like Det smelter en is i solen ("there melts an ice cream in the sun') the paraphrase 'There is an ice cream in the sun such that it is melting' is infelicitous. Location is predicated of the entire event in these cases.

\subsection{The Syntax of Unergative IECs}

\subsubsection{A Small Clause Analysis}

The particular syntactic and semantic properties seen with unergative IECs as well as the similarity they bear to expletive copula constructions is straightforwardly captured if we assume that the group of unergatives occurring in IECs have the option of combining with a small clause complement. On analogy to small clause analyses of copula constructions (e.g. Stowell 1978, Bowers 1993, 2002, Hazout 2004), I propose that the unergative verbs that occur in IECs subcategorize for a small clause complement containing a locational predicate (either PP or AP). The unaccusative nature of these structures stems from the absence of en external argument in Spec-vP (i.e. an "unaccusative" little v). An initial version of this structure is given in (32).

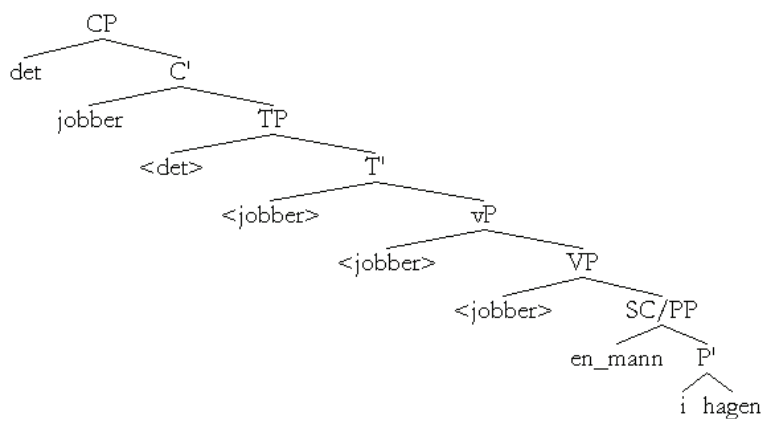

This analysis straightforwardly captures the complement-like behavior of the locational predicate as well as the coordination facts. Interestingly enough, the small clause analysis relates the unergative IECs to other constructions where what looks like a direct object is assumed to actually originate as a small clause subject, most notably adjectival resultatives in English (e.g. Kratzer 2004).

The structure in (32) in turn raises several theoretical questions, most significantly regarding the relation between unergatives and external (agentive) argu-

Likewise, we do not find non-locational adjectivals preceding the thematic subject in Norwegian.

(ii) There were three students drunk/*Det var tre studenter fulle. 


\section{Unergatives in Norwegian Expletive Constructions}

ments, theta-assignment, and whether (32) has non-expletive counterparts.

\subsubsection{The Relation Between Unergatives and External Arguments}

The analysis in (32) assumes that unergatives in some cases occur without an external (agentive) subject. Note that this assumption differs in a subtle, yet important way from what we saw with the unified IEC accounts. The unified analyses argue against the common assumption in linking theory that agents are always realized as syntactic subjects: they may also map onto the object position in certain cases. These accounts thus assume that unergatives have one lexical entry, and that the difference between regular unergative intransitives and unergative IECs originates in the lexicon-syntax interface. ${ }^{4}$ The analysis presented here assumes that multiple lexical entries are what gives rise to different syntactic structures. The agentive intransitives results from a "bare" unergative combining with $v$ selecting an external argument. The unergative IECs are a result of the verb subcategorizing for a small clause complement, and combining with an agent-less (i.e. "unaccusative") $v$.

In short, while it follows from the unified IEC accounts that agents are not necessarily realized as subjects, the current analysis assumes that unergative verbs do not necessarily occur with agents. This presupposes a constructional view on the external argument: on the view that external arguments are assigned structurally through the mediation of a functional head (Kratzer 1996, Marantz 1997 among others), we may allow for the option that unergatives in certain cases occur without an agentive functional projection.

\subsubsection{Theta Assignment}

Another question that needs to be addresses is how the DP receives a $\theta$-role from the verb in these constructions. A short recapitulation of the core semantic properties of unergative IECs is in place here. There is consensus in the literature that unergative IECs are de-agentivized relative to regular (non-expletive) unergative constructions (e.g. Maling 1987, Lødrup 1999) and are best characterized as involving presentational focus in the sense of Bresnan (1994). "[...] a scene is set and a referent introduced on the scene to become the new focus of attention" (Bresnan 1994:91). A scene is naturally expressed as a location and the referent as something of which this location is predicated, i.e. a theme. This description applies to Norwegian expletive copula constructions and unergative IECs alike. In unergative IECs this state is additionally characterized as working, playing, etc., as was discussed in section 4.1.

As a way of both capturing these semantic facts and accounting for $\theta$ assignment, we could assume that thematic subjects in unergative IECs receive two $\theta$-roles. The first is assigned within the small clause itself. The second is assigned through short $\theta$-driven movement of the DP to Spec-VP. Along the lines

\footnotetext{
${ }^{4}$ A related idea is found in Bresnan's 1994 analysis of Locative Inversion in English: a locativetheme frame, or "thematic overlay" is imposed on the argument structure of an agentive verb as a pragmatic requirement.
} 
of Hornstein (1999) we have to assume that $\theta$-roles are features of the verb that can drive movement, and that nominals may receive more than one $\theta$-role. ${ }^{5}$

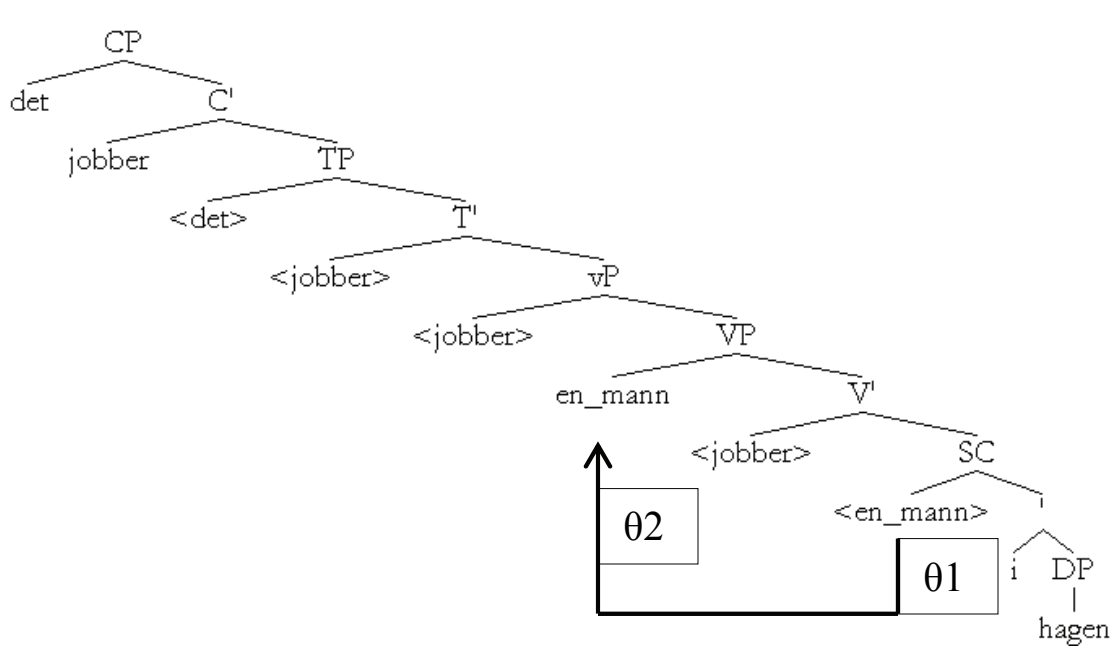

The structure in (33) involves a case of what Jeong (2006) calls "literal object sharing": co-indexation of objects via movement where the syntax forces the semantics to interpret the subevents that relate to the shared object as connected parts of a whole event structure (Jeong 2006:3). In this sense, the DP-movement assumed in (33) reflects the two semantic components that constitute the meaning of unergative IECs.

There is (at least) one significant remaining challenge for the analysis in (33) however: what to make of the Spec-VP position. If we take (33) to be the correct analysis of unergative IECs, not only do we have to assume that unergatives may occur without an agent and in combination with a small clause complement, but we also have to assume that they license a Spec-VP. I argued earlier that the lack of an external argument receives justification from the little- $v$ hypothesis. Unergatives have been assumed to combine with small clauses in adjectival resultatives (e.g. John ran himself tired). But that unergatives may license a Spec-VP position deviates from any previous assumptions about the syntax of unergatives. By positing this rather unaccusative property, we arrive at some of the same problems that arise with the unified IEC accounts, albeit via a different route. Although the current analysis does provide a more adequate account of the syntactic and semantic properties of unergative IECs, the actual occurrence of unergative verbs in this structure remains as a rather puzzling fact of Norwegian syntax.

\subsubsection{Do unergative IECs have non-expletive counterparts?}

The last question to be addressed in this section is whether unergative IECs have

\footnotetext{
${ }^{5}$ Note that moving the small clause subject to Spec- $v \mathrm{P}$ gets the word order wrong in sentences when the main verb does not move to $T$, unless we stipulate additional verb-movement to some lower projection above $v \mathrm{P}$ in these cases. Assuming movement to Spec $\mathrm{P}$ would also face some trouble explaining the de-agentivized flavor of these constuctions.
} 


\section{Unergatives in Norwegian Expletive Constructions}

non-expletive counterparts. With unergatives, we would expect a non-expletive unergative intransitive to be ambiguous between a non-expletive counterpart to IECs (34) and a regular agentive intransitive with an adjunct PP (35), i.e. between an existential and an agentive reading.

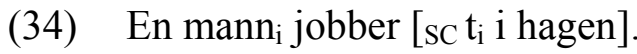

(35) En mann $_{i}\left[{ }_{\mathrm{vP}} \mathrm{t}_{\mathrm{i}}[\mathrm{vP}\right.$ jobber]] [pP $\mathrm{i}$ hagen].

As an initial speculation, it is interesting to note that unergatives with indefinite subjects have been claimed to often yield a modal marking of the indefinite subject: "[...] a kind of objective reference, used e.g. when telling a joke or describing a picture" (Lødrup 1999:214). This "objective reference" could be a reflection of the structure in (34). Whether non-expletive unergative intransitives actually are ambiguous in the way my analysis predicts still remains to be properly tested.

\section{Summary}

The primary theoretical focus of this paper has been on how to go about analyzing the unexpected occurrence of unergative verbs in intransitive expletive constructions in Norwegian. I started out by showing that analyses unifying unergative and unaccusative IECs are empirically inadequate. I further argued that the close syntactic and semantic relation we find between unergative IECs and expletive copula constructions supports an analysis of unergative IECs as verbal existentials, where unergatives combine with a small clause complement, without an external argument. The difference between agentive and copular use of unergatives was assumed to be rooted in core syntax rather than resulting from a "pragmatic overlay" of some sort.

\section{References}

Borer, Hagit. 2004. The Grammar Machine. In A. Alexiadou, E. Anagnostopoulou and M. Everaert, eds., The Unaccusativity Puzzle-Explorations of the Syntax-Lexicon Interface. New York: Oxford University Press.

Bowers, John. 1993. The Syntax of Predication. Linguistic Inquiry 24:591-656.

Bowers, John. 2002. Transitivity. Linguistic Inquiry 33:183-224.

Bresnan, Joan. 1994. Locative Inversion and the Architecture of Universal Grammar. Language 70:72-131.

Hazout, Ilan. 2004. The Syntax of Existential Constructions. Linguistic Inquiry 35: 393-430.

Hoekstra, Teun A. and René Mulder. 1990. Unergatives and Copular verbs: Locational and Existential Predication. The Linguistic Review 7:1-79.

Hornstein, Norbert. 1999. Control and Movement. Linguistic Inquiry 30:69-96. 
Kjersti G. Stensrud

Kratzer, Angelika. 1996. Severing the External Argument from the Verb. In J. Rooryck and L. Zaring, eds., Phrase Structure and the Lexicon, 109-37. Dordrecht: Kluwer.

Kratzer, Angelika. 2004. Building Resultatives. Ms., University of Massachusetts, Amherst.

Levin, Beth. 2005. Argument Realization. Cambridge: Cambridge University Press.

Lødrup, Helge. 1999. Linking and Optimality in the Norwegian Presentational Focus Construction. Nordic Journal of linguistics 22:205-230.

Maling, Joan. 1987. Existential Sentences in Swedish and Icelandic: Reference to Thematic Roles. Working Papers in Scandinavian Syntax 28.

Marantz, Alec. 1997. No Escape from Syntax: Don't Try a Morphological Analysis in the Privacy of Your Own Lexicon. U Penn Working Papers in Linguistics 4(2):201-225.

Mikkelsen, Line Hove. 2001. Reanalyzing the Definiteness Effect: Evidence from Danish. Rutgers Optimality Archive 470-1001. http://roa.rutgers.edu.

Platzack, Christer. 1983. Existential Sentences in English, Swedish, German and Icelandic. In F. Karlsson, ed., Papers from the Seventh Scandinavian Conference on Linguistics, 80-100.

Stowell, Tim. 1978. What Was There Before There Was There. In D. Farkas, W.M. Jacobsen and K. W. Todrys, eds., Papers from the 14th Regional Meeting of the Chicago Linguistics Society, 458-471.

Sveen, Andreas. 1997. Norwegian Impersonal Actives and the Unaccusativity Hypothesis. PhD diss, University of Oslo.

Kjersti G. Stensrud

University of Chicago

Department of Linguistics

1010 E. $59^{\text {th }} \mathrm{St}$

Chicago, IL 60637

kgs@uchicago.edu 